\title{
Helge Grell in memoriam
}

1915- 2000

Et tilbageblik på Helge Grells livsløb og forfatterskab efterlader umiddelbart det indtryk, at der her var tale om en præst, hvis hele virke var præget af hans engagement inden for den brogede mangfoldighed af grundtvigske folkelige organisationer, og samtidig om en teologisk forskerpersonlighed, der gjorde det til en livssag at yde et bidrag til den fagteologiske forståelse af Grundtvig og hans betydning for nutiden.

Ser man nøjere til, var Helge Grells liv markeret af afgørende historiske milepæle i udforskningen i det 20. årh. af Grundtvig og hans virkningshistorie. I Grells studietid i slutningen af trediverne fulgte han det store opgør om Grundtvig-tolkningen, den indsigelse, der fra Knud Hansen og Kaj Thaning blev rettet mod den kirkelige grundtvigianisme, personificeret i Anders Nørgaards standpunkt, bestemt af de unge »tidehvervsgrundtvigianeres « fordring om at lade solidaritet med den folkelige virkelighed træde i stedet for en påstået kirkelig indelukkethed i den tidligere grundtvigske tradition, der var præget af den kirkelige vækkelse. Da Grell få år senere havde afsluttet sit studium og fik embede som præst, var den historiske ramme den folkelige rystelse og efterfølgende mobilisering under den tyske besættelse. Hal Kochs berømte Grundtvig-forelæsninger har utvivlsomt virket som et incitament for Grell i de første år som præst. I alt fald er det nærliggende at se hans senere mangeårige indsats i det grundtvigske organisationsnetværk som opfølgning af det indtryk, han modtog, da Koch i de første besættelsesår rejste land og rige rundt for at medvirke til bevidstgørelse om folkestyret og dansk kulturarv som værn mod totalitarismens menneskesyn. I de første år efter befrielsen blev de første bidrag til en fornyelse af Grundtvig-forskningen inden for rammerne af det netop grundlagte Grundtvig-Selskab af 1947 lige så åbenbart igangsættende for Grell. Navnlig Henning Høirups disputats, men også C.I. Scharlings afhandling om Grundtvig og romantikken var banebrydende og kaldte på at blive taget op og videreført. Det var dog fremdeles således, at hans opmærksomhed var rettet mod Kaj Thanings position, der i 1963 nåede et monumentalt højdepunkt med disputatsen »Menneske først - «. I-III, 1963. Thanings afhandling blev for Grell den udfordring, der - med al anerkendelse og enighed med Thaning i udgangs- 


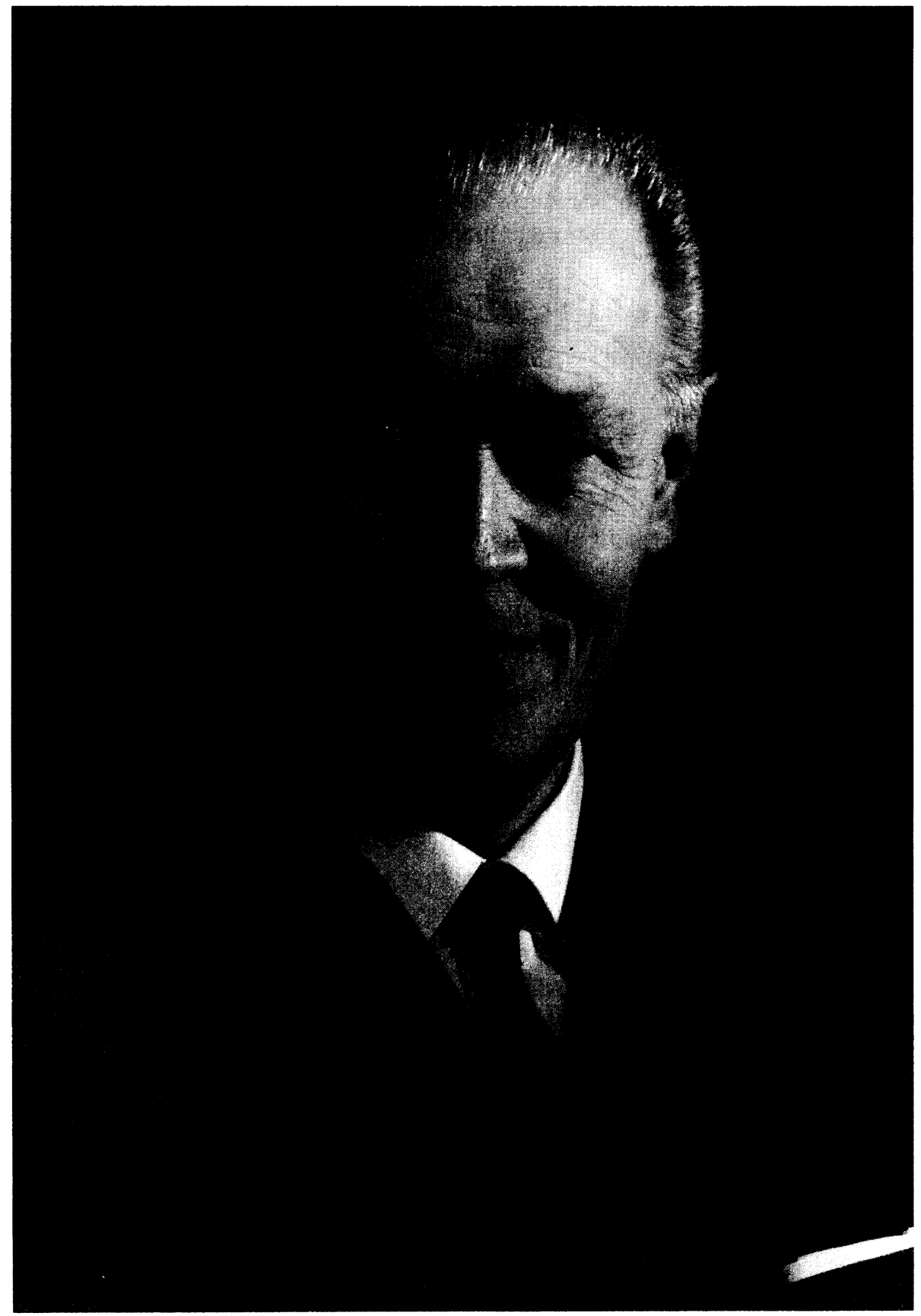


punktet - dog alligevel kaldte på en differentierende replik og videreførelse. Grells faglige trang til at komme videre med sin egen Grundtvig-forståelse blev så intens, at han lod sig pensionere forholdsvis tidligt for dermed at kunne koncentrere sig fuldt ud om affattelsen af en disputats. Arbejdet blev fuldført i 1988 med forsvaret af de to bøger »Skaberordet og billedordet « og »Skaberånd og folkeånd. En undersøgelse af Grundtvigs tanker om folk og folkelighed og deres forhold til hans kristendomssyn".

Det kan således fastslås, at der aftegner sig en klar indre sammenhæng i den teologiske udvikling, Grell gennemgik fra studenterårene helt frem til disputatsen og de efterfølgende offentliggørelser, der kom til at fylde hans usædvanligt virksomme otium. Følgelig vil det være misvisende, hvis man antog, at der var tale om to adskilte faser i Grells liv, først præstegerningen suppleret med en indsats som foredragsholder og underviser på flere forskellige skoleniveauer samt deltagelse i folkeligt organisationsarbejde; dernæst i de sene år forskerindsatsen, der blev videreført indtil det sidste. Nej, adskilte faser var der langtfra tale om. Snarere må man sige, at de mange år som præst, underviser, foredragsholder og bestyrelsesmedlem sammen med en usvækket optagethed af de ovenfor omtalte bidrag til Grundtvig-forskningen fremkaldte en stadig større beslutsomhed hos Grell om at yde et selvstændigt bidrag til drøftelsen. Sammenhængen mellem det kirkelig og folkelige virke i manddomsårene og forskningsarbejdet i pensionistårene var Grell sig ganske bevidst. Han så det åbenbart som afbetaling på en taknemmelighedsgæld, når han i sine bøger søgte klarhed om de problemstillinger, han hele sit liv havde været optaget af, men som fordrede nuancering og tydeliggørelse. Grells bøger, hele fem blev det til, var bestemt af et ønske om at medvirke til en klaring af nogle vigtige debatemner, der havde været bestemmende siden ungdomsårene. Nok drømte Grell aldrig om at løbe fra arv og gæld i forhold til denne grundtvigske tradition, men der var dog tale om en kritisk solidaritet. Han følte det i stigende grad utilfredsstillende, at bestemte grundtvigske slagord syntes at være blevet fælleseje, når forholdet ved nærmere eftersyn viste sig at være det, at disse slagord alt for ofte blev fremført uden præcision og bevidsthed om den saglige sammenhæng. På den anden side følte Grell sig ikke kaldet til at fremføre nye simple deviser til 
erstatning for de uklare etiketter, der stod i vejen for en konstruktiv videreførelse af den grundtvigske arv. Men han var overbevist om, at en nøjere historisk og systematisk analyse af begrebernes egentlige indhold i længden ville være til gavn, i folkekirkelig sammenhæng lige så vel som folkeligt-kulturelt.

Dette anliggende gjorde Grell tydeligt opmærksom på, da han tog stilling til nogle af de diskussionsindlæg, der fremkom i forbindelse med disputatsforsvaret.

»Både i folkekirkelig og folkelig sammenhæng er den grundtvigske bevægelse præget af en bredde og mangfoldighed, som ikke skal lægges den til last. Men det lader sig ikke skjule, at dette forhold har medført en konturløshed, som ikke er blevet mindre af, at man i grundtvigske kredse ofte har gjort en dyd af ikke at formulere sig klart om sit grundlag. I stedet har man dyrket en forudsat indforståethed som erstatning herfor med en henvisning til, at det her drejer sig om forhold, man kun kan indleve sig i, og som ikke lader sig udtrykke med præcise bestemmelser. - Man holder sig til en række stående Grundtvig-citater som 'menneske først og kristen så', 'kun ved badet og bordet hører vi Guds ord til os', 'ordet af Herrens egen mund' osv., uden at forsøge en nærmere bestemmelse af deres indhold. Også i dette forhold kan man i forbindelse med mit personlige engagement i den grundtvigske bevægelse, både kirkeligt og folkeligt, finde en medvirkende årsag til, at jeg netop har vendt mig mod de to emner, som mine to bøger omfatter, og til den synsvinkel, jeg har anlagt på disse emner«.

Der var således en klar, indre sammenhæng mellem eksistentielle erfaringer fra hans livsgerning og hans ønske om at bidrage til en konstruktiv videreførelse af den videnskabelige udforskning af Grundtvig. Men der var tillige tale om en udvikling, der inden for Grells livsforløb afspejler en væsentlig udvidelse af horisonten for arbejdet med Grundtvig. Mens det $i$ hans unge år var den nationale udfordring for danskheden, der påkaldte sig hele opmærksomheden, blev det i de senere år i stadig højere grad en uafviselig del af hans forehavende at tage det »universelle« perspektiv hos Grundtvig for pålydende. Det håndterede 
Grell på den måde, at han gav sig i kast med en detaljeret analyse af Grundtvigs Englands-rejser. Dette skete vel at mærke ikke alene ud fra et ønske om dermed at bidrage til forståelsen af nogle hidtil uafdækkede eller dunkle aspekter af Grundtvigs udvikling, men også med et klart forsæt om at søge klarhed om Grundtvigs nutidige relevans i internationalt perspektiv.

Det er umuligt inden for rammerne af disse mindeord at give en blot nogenlunde udtømmende karakteristik af Grells bøger. Men nogle få markante synspunkter skal omtales i håb om, at de kan formidle et indtryk af rækkevidden af Grells bidrag til Grundtvig-forskningen.

Bogen »Skaberånd og folkeånd. En undersøgelse af Grundtvigs tanker om folk og folkelighed og deres forhold til hans kristendomssyn«(1988), det væsentligste af de to værker, der tilsammen gav ham doktorgraden, er utvivlsomt den mest helstøbte af samtlige 5 bøger. Den udmærker sig ved at belyse udviklingslinjer gennem hele Grundtvigs forfatterskab, idet Grell dermed vil nå frem til en mere nuanceret forståelse end den tidligere faglitteratur, hvilket søges opnået gennem orientering ud fra de enkelte momenters plads i helheden.Dermed lægger han afstand til de forskellige forsøg på at udhæve et enkelt vendepunkt som det altafgørende gennembrud. Samtidig søger han at skitsere et mere differentieret syn på hovedproblemet, forholdet mellem det menneskelige og det kristelige. »Men selve det forhold, at han gennemløber en historisk udvikling, hvor menneskelighed, folkelighed og kristendom knyttes stadig tættere til hinanden i hans opfattelse, indebærer ikke, at de hver for sig skulle miste en selvstændig betydning. For ham er der hermed tale om at hævde en sammenhæng inden for den samme skabergernings historie. Her skal menneskelighed og folkelighed ikke hente deres legitimation fra kristendommen, lige så lidt som det modsatte er tilfældet. Det er det samme skaberord, som lyder 'i begyndelsen', virker i folk og folkelighed og fremtræder som genløsningsordet i den kristne menighed. Netop dette betinger det vekselvirkningsforhold mellem de to områder, som Grundtvig stadig vender tilbage til«.

Samme noble bestræbelse på et formidlende, syntetiserende synspunkt finder man i Grells første bog om Grundtvigs Englandsrejser »England og Grundtvig« (1992). Heri ligger der ganske klart en kritisk replik til Kaj Thaning, men 
ikke nogen konfrontationspræget antitese, snarere et ønske om en afbalanceret, konstruktiv videreførelse. Med dette udgangspunkt gør Grell sig stor ulejlighed for at påpege, at analysens formål ikke er begrænset til en undersøgelse af detaljer i Grundtvigs udvikling, heller ikke til en historisk kortlægning af påvirkninger, inspirationskilder mm. I stedet er det Grell om at gøre at kombinere en historisk redegørelse for Englandsrejserne med en principiel tolkning af synspunkternes betydning ud fra en systematisk-teologisk vurdering.

»Betydningen af Englandsopholdene er ganske anderledes gennemgribende end som så. Grundtvigs egen vurdering af dette forhold går ud på, at han indtil Englandsrejserne så med middelalderlige øjne på nordiskheden og dens betydning, dvs. med det menneske- og historiesyn, han indtil da var kommet frem til. Med »middelalderlige øjne« mener han, at dette syn var uden forbindelse med nutiden. Med dette syn ville han erobre England og det engelske folk. Det lykkes ikke, men i stedet bliver han i England konfronteret med, hvad han betegner som »den borgerlige side af nordiskheden«, d.v.s. den håndgribelige virkelighed på en måde, som tvinger ham til at tage sit middelalderlige syn op til revision. Det fører til hans endelige formulering af sit menneskesyn $\mathrm{i}$ indledningen til Nordens Mythologi 1832, af sin universalhistoriske anskuelse og til den sondring mellem anskuelse og tro, som bliver forudsætning for hans syn på videnskabelighed og almen oplysning, på kirken som formidler af en sådan oplysning og på forholdet mellem stat og kirke og på samarbejdsmuligheder på dette område«.

I sådanne udsagn mærker man alderdommens modenhed hos Grell, en søgen efter helheder, der forener. Samtidig aner man en bestræbelse på at sammenfatte et langt livs optagethed af Grundtvig og lægge det frem for nutiden som et standpunkt, hvis betydning i kirke og folk Grell ikke et øjeblik tvivler om.

Den næste bog »Grundtvig og Oxforderne«(1995) omhandlede på tilsvarende måde den fjerde rejse i 1843. Så var kræfterne endda ikke opbrugt. Men Grell gav sig i kast med endnu en bog, nu om Grundtvigs højskoletanker og deres videreførelse, respektive omtolkning i de efterfølgende generationer, ॥Vi- 
sion og virkeliggørelse« (1998). Også denne bog fremlagde en mængde stof, der vidnede om en myreflittig forskerpersonlighed, men bogen var samtidig vidnesbyrd om, at kræfterne var svindende i henseende til en afsluttende bearbejdelse af manuskriptet.

Tilbage står dog, at de fem Grundtvig-bøger, offentliggjort mellem $1980 \mathrm{og}$ 1998 , vidner om en betydelig forskningsindsats, formet af et mangeårigt virke i kirke, undervisning og folkeliv.

Jens Holger Schjørring 